\title{
Corrigendum: Service quality perceptions of campus-based food outlets
}

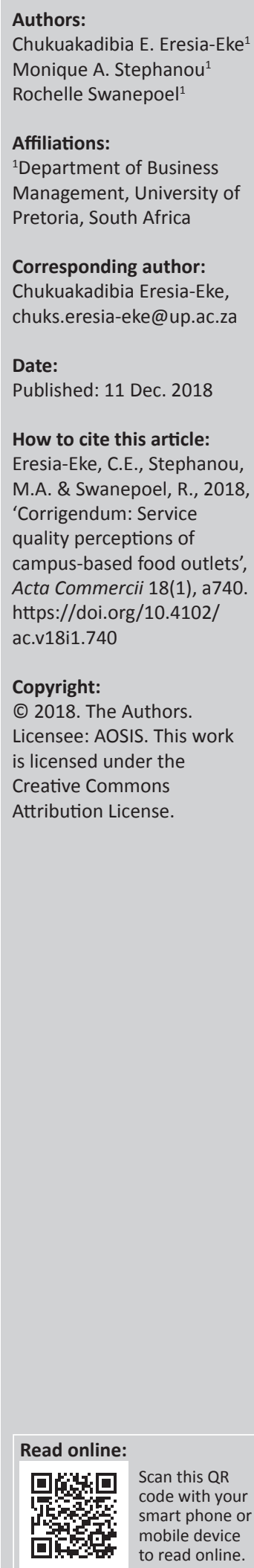

Chukuakadibia E. Eresia-Eke ${ }^{1}$ Monique A. Stephanou ${ }^{1}$

Rochelle Swanepoel ${ }^{1}$

\section{Affiliations:}

${ }^{1}$ Department of Business

Management, University of

Pretoria, South Africa

Corresponding author:

Chukuakadibia Eresia-Eke,

chuks.eresia-eke@up.ac.za

Date:

Published: 11 Dec. 2018

How to cite this article:

Eresia-Eke, C.E., Stephanou, M.A. \& Swanepoel, R., 2018,

'Corrigendum: Service quality perceptions of campus-based food outlets', Acta Commercii 18(1), a740. https://doi.org/10.4102/ ac.v18i1.740

\section{Copyright:}

(C) 2018. The Authors.

Licensee: AOSIS. This work

is licensed under the

Creative Commons

Attribution License.

Scan this QR

In the author list of this article initially published, Monique A. Stephanou's first name was unintentionally misprinted as 'Mon'. The correct first name is 'Monique'. The author sincerely apologises for any inconvenience caused. 


\section{Service quality perceptions of campus-based food outlets}

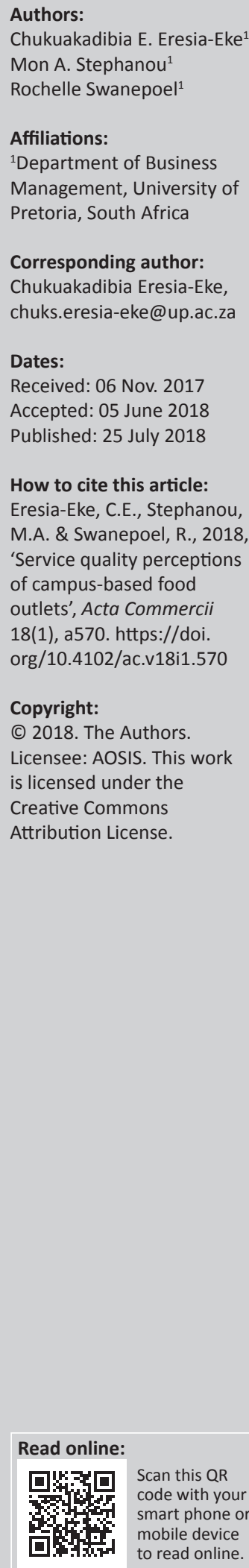

Orientation: In a competitive retail business environment, the essence of service quality is invariably amplified. Within a university context, the same applies, given that the student population of customers is relatively finite and yet there are a variety of food outlets on campuses.

Research purpose: This study aims to investigate the existence (or lack of it) of a relationship between gender, race and price and the dependent variable of students' service quality perception of campus-based food outlets. Although gender and race are the most obvious defining demographic features of a student population, the variable of price is usually a major consideration for student purchases.

Motivation for the study: The study is an applied research as it is focused on addressing an issue with real-life business implications.

Research design, approach and method: It employs the use of data collected in a crosssectional manner from 200 respondents selected through non-probability sampling.

Main findings: The findings of the study indicate that no significant differences exist in service quality perception when gender is considered. Conversely, results show that the service quality perceptions of racial groups differ. The study also finds that a weak but positive correlation exists between price and service quality perceptions.

Practical/managerial implications: These results indicate practical implications as they can become useful condiments for refining the offerings and services of the studied campus-based food outlets in the quest to meet or exceed customer expectations.

Contribution/value-add: From an academic perspective, the study builds on existing knowledge by exposing the association that the independent variables of gender, race and price have with students' service quality perception in the specific context of campus-based food outlets in Gauteng, South Africa.

\section{Introduction}

In the current environment in South Africa, businesses face numerous difficulties (Denton \& Vloeberghs 2003:86) possibly related to political instability, slow economic growth, rising interest rates, market volatility, a vulnerable currency, disruptive technology, radical innovation, new competitors, changing demographics, rising inflation and onerous regulation. These have catalysed a re-imagining of business strategies in an intensely competitive business environment. Typically, businesses are faced with the challenge of maintaining a superior product offering as they are easily copied, resulting in a significant shift from a previously manufacturing-dominant industry to a more service-reliant industry (Dabestani et al. 2016:160; Kilinc et al. 2013:5). Further, consumer demands have evolved significantly and this has ramifications for customer perceptions of service quality. Against this background, it would seem that, in modern-day businesses, the quality of the service offering and its consistent delivery could be the main differentiating factors that contribute to a competitive advantage.

Consequently, managers of service-oriented organisations, such as food outlets, need to focus on providing better services in order to earn a positive service quality perception, customer satisfaction and repeat patronage (Prentice 2013:50). It is worthy to note that these concepts can become quite fluid and, in practice, the likelihood of discordance in the estimation of the levels of these concepts between managers and customers remains a reality. Indeed, within a university context, Cao and Kim (2015:100) state that the discrepancy that often exists between management's perceptions of service quality and those of students is an important point to note. Because of this 
assertion, this study elects to attempt a measurement of service quality perception from the student's perspective, partially motivated by Sumaedi, Bakti and Metasari's (2012:165) opinion that in a university setting, students are the main consumers, and thus their perception of service quality is of utmost importance. Part of the motivation for the choice of a university is linked to the reality that such institutions are populated by youths who are the important patrons of food outlets and whose choices, preferences and decisions may well define tomorrow's customers' expectations of retail food businesses in larger society.

Scholars like Cao and Kim (2015); Chou, Wu and Huang (2014); Dabestani et al. (2016); Du Plooy, De Jager and Van Zyl (2013); Kanta and Srivalli (2014); as well as Ryu, Lee and Kim (2011) have devoted some of their efforts to the study of service quality. The SERVQUAL model is the common denominator in these studies and has become an established tool for measuring service quality in different industries. Indeed, the value of the SERVQUAL model is better appreciated in the light of its position as the progenitor of others like the SERVPERF model (Domenge \& Arciniega 2015:13) and the GAP model of Service Quality (Parasuraman, Zeithaml \& Berry 1985:44) which have also been used in studies of service quality.

In a continent where issues of gender remain topical and in a country where the population continues to be polarised along racial lines because of the legacy of apartheid, it would be interesting to investigate how these factors that relate to a kaleidoscope of societal issues also link with service quality in a youthful population. In the context of race groups, for instance, it would be interesting to ascertain if service quality is coloured by racial preferences, in the light of the fact that race often is a common denominator of social discourse in South Africa. The study gathers additional impetus given that it is located within a student environment and students usually have to make important buying choices in the face of strict financial constraints and so price almost always becomes a critical consideration. Recourse to the use of a university for this study is appealing because it is an organisation that serves as an incubator for tomorrow's opinion leaders. Consequently, a knowledge of the perceptions of this group of people may provide valuable insights that could enrich the efforts of campus-based food outlets to remain sustainable into the future. Driven by this thinking, the study aims to:

- measure students' perception of service quality of campus-based food outlets

- establish the existence or otherwise of a difference between male and female students' service quality perception of campus-based food outlets

- determine the race-related difference, if any, in the levels of students' service quality perception of campus-based food outlets

- investigate whether a relationship exists between price and the service quality perception of students with respect to campus-based food outlets.
Enhanced service quality can enable a business to achieve a competitive advantage (Singh \& Zheng 2014:256), customer satisfaction (Rauch et al. 2015:88) and customer loyalty. It is also likely to enhance the image of the business (Dedeoglu \& Demirer 2015:130). According to Du Plooy et al. (2013:95), understanding and meeting customers' needs is crucial for the success of a business, and so it is vital for business survival to understand customers' perception of service quality. These thoughts, collectively, lend credence to the need for this study.

\section{Literature review}

Although a number of studies have been conducted on service quality perception, they are all affected to differing extents by the lack of consensus among researchers when the concept of quality is the concern (Ltifi 2013:2). This perhaps stems from the reality that quality is such a fluid concept that it inevitably means different things to different people. Despite this discordance, there is some agreement in the literature as it concerns the issue of service quality, and this relates to the fact that customer perceptions are vital in service organisations (Jiang et al. 2012; Duggal \& Verma 2013; Parasuraman, Zeithaml \& Berry 1988). Customer perceptions reveal what is valued in the market and what the most important aspects of a service are (Duggal \& Verma 2013:135). Therefore, there is no gainsaying the fact that a knowledge of this can be priceless in the scheme of honing strategies to grow the organisation.

According to Jiang and Wang (2006:212), service quality perception is defined as a consumer's evaluation of the service performance received, compared with their expectations. With respect to what makes up service quality, Parasuraman et al. (1988:5) contend that it consists of the result of the service and the process of delivery. A similar opinion is canvassed by Draai and Raga (2012:186) who propose that there are two components for service quality, namely functional and image quality. While functional quality involves the process of delivering services that meet predetermined requirements, image quality relates to a business's reputation and how consumers perceive the business. As it concerns approaches, Domenge and Arciniega (2015:12) contend that service quality involves two main approaches: internal and external. The internal approach encapsulates the process or steps that service providers take in order to provide a service, whereas the external approach considers the customers' service quality perception and focuses on their service expectations. This study's position is that while the internal approach may qualify as a 'means', the desired 'end' is clearly associated with the external approach. This is largely why the study simply focuses on the service quality perception of the customers, who in this specific case are students.

Within the context of a university, Karna and Julin (2015:47) found that differences exist between students and staff on the one hand and also across campus locations on the other hand, as it pertains to features of satisfaction with the educational 
service offered at a university. Judson and Taylor (2014:54) noted the existence of differences in students' service quality perceptions although these differences were unrelated to their study's independent variable of students' grades. In Indonesian universities, Sumaedi et al. (2012:164) sought to identify the useful dimensions of students' perceived service quality by considering the socio-demographic characteristics of 155 students. The findings of their study revealed that there was a difference between perceived service quality of male and female students as it concerns social activities. These studies hint at the possible existence of differences in service quality perceptions of a student population as dictated by certain idiosyncrasies of the groups under consideration. The results of the studies cannot however be relied upon to draw any reasonable conclusions about service quality perceptions in dissimilar contexts, and this justifies the effort aimed at investigating the specific case of campusbased food outlets in the peculiar setting of South Africa, given the country's unique history.

It is instructive to acknowledge that various models have been developed to allow researchers to measure service quality, as it is an abstract construct that deals with the emotions and feelings of consumers. Parasuraman et al. (1985:44) developed the GAP model to measure and analyse the perception of client satisfaction with service quality. The model highlights four gaps (expectation gap, the standards gap, the performance gap and the communication gap) that allow the identification and analysis of the difference between expected service quality and the performance experienced. The central thrust of the model is to bridge the gap between expected performance and actual performance (Draai \& Raga 2012:189).

Cronin and Taylor (1992) developed the SERVPERF model to evaluate the perception of service quality. This model varies from others as only the actual performance of the service is taken into account. Therefore, it essentially suggests that a single measure is required and will only be considered once a service is provided. Rust and Oliver (1994) developed a model of three dimensions, which act as key components of service quality perception. These dimensions include environment, staff and product. Parasuraman, Berry and Zeithaml (1991) developed the SERVQUAL model, which is most commonly used for the measurement and conceptualisation of constructs of service quality. The SERVQUAL model originally comprised 10 dimensions used to analyse levels of service quality. These 10 dimensions consist of tangibles, reliability, responsiveness, security, competence, courtesy, credibility, communication, access and understanding the client (Draai \& Raga 2012:189). However, from the 10 dimensions, $\mathrm{Wu}$, Huang and Chou (2014:175) identified the dominant dimensions of service quality as those of tangibles, recovery, responsiveness and knowledge.

The DINESERV model developed by Stevens, Knutson and Patton (1995) seems to have been inspired by SERVQUAL's dimensions. Indeed, Kim, Ng and Kim (2009:11) modified the model and recognised six dimensions, namely value, atmosphere, convenience, food quality, service quality and price. According to Gagic (2013:169), the use of DINESERV within a university context could assist food outlets in improving customer satisfaction and increase students' patronage. The DINESERV model is also able to measure customer satisfaction, repeat patronage and word-of-mouth in food outlets (Cao \& Kim 2015:105; El-Said \& Fathy 2012:322)

Clearly, although all these models target the measurement of service quality, each of them tends to emphasise particular dimensions as being of critical importance in the service quality equation. In the light of this, the researcher is therefore at liberty to use whichever model is considered to best serve the purpose of a study. Consequently, the questionnaire utilised for the measurement of service quality in this study is an instrument that combines the SERVQUAL and DINESERV models given that the study's focus was on food outlets and the prime intention was to determine how the independent variables of gender, race and price relate with the students' service quality perception.

\section{Gender and service quality perception}

Previous studies have investigated the role of gender in service quality perceptions in different contexts (see Du Plooy et al. 2013; Josiam et al. 2014; Kanta \& Srivalli 2014; Lin et al. 2014; Lu \& Wang 2015; Mokhlis 2012; Sumaedi et al. 2012). Interestingly, these studies have generated mixed results and exposed a lack of consensus on the existence of an association between gender and service quality perception. Some studies (Lu \& Wang 2015; Mokhlis 2012; Sumaedi et al. 2012) concluded that gender has an influence on service quality perceptions as men and women's perceptions differ. It is noteworthy though to highlight the lack of consensus among this cohort of studies as results reflect different conclusions concerning the specific leanings of male and female perceptions. There are also other studies (Du Plooy et al. 2013; Josiam et al. 2014; Lin et al. 2014) that contend that there is no evidence to suggest that gender relates to service quality perception.

In a study to determine whether customers were satisfied with the service quality delivered by informal grocery retail stores in Gauteng, South Africa, Du Plooy et al. (2013:110) found that there were no significant differences across gender groups in relation to the average ratings obtained for service quality. Conversely, Mokhlis's (2012:103) study of customers' service quality perceptions of municipalities in Thailand revealed that while men attached greater importance to the factors of empathy, tangibles and reliability in comparison with women, both genders equally valued the assurance and responsiveness factors. In their study, Josiam et al. (2014:61) found that a significant difference exists between male and female patrons' service quality perceptions of restaurants as men were concerned with 
matters of ambience and alcohol provision which women did not particularly deem to be important.

Because of the discordance in results of studies investigating the association of gender with service quality perception, it can be inferred that context may be critical to the findings. The implication of which is that none of the results obtained in previous studies can be relied upon to predict the possible outcome within a university in South Africa. However, although the student population may be heterogeneous in composition, a certain degree of homogeneity exists in the sense that they are all students in a particular phase of life. Because of this, the expectations of this cohort of people as it pertains to service quality may not be substantially polarised. The study believes that students in a campus setting belong in the same communal environment, the majority of them possibly fall within similar age brackets and all of them are typically subject to relatively similar conditions. Against this background, it would seem reasonable to project that they may have more in common compared to the things that differentiate them. Consequently, the singular gender difference may not substantially affect their service quality perceptions of food outlets, and so in the specific context of this study, it is hypothesised that:

$\mathbf{H}_{1}$ : There is no difference between male and female students service quality perception of campus-based food outlets.

\section{Race and service quality perception}

The issue of race is a common one in South Africa, given its history of apartheid. Race generally tends to define relationships, decisions and positions in the country. This is why Maumbe (2012:152) argues that the observation of different racial groups in South Africa is vital to the survival and profitability of restaurants. Differences in service quality perceptions across racial lines may have historical explanations drawn from the group areas act of the then apartheid government which meant that black townships were traditionally established with minimal shopping and other facilities. Because of this, commercial and Western food outlets, for instance, were not as prevalent in black townships as they were in white suburbs. Despite the historical and geographical differences, Terblanche and Boshoff (2010:1) found no racially induced differences in the service quality perceptions of patrons of fast-food outlets save for the fact that when compared to other race groups, people of mixed race perceived that the value of the offerings were significantly higher.

Race can spell ethnic and cultural identity and this is linked to the preservation or loss of attitudes and behaviours, as informed by a person's culture. With respect to food outlets, the perceived service quality of racial groups may be dissimilar as the act of eating has the ability to reveal an association to a specific group as well as its routines and consequently generate a sense of identity (Fonseca 2008:29). This position suggests that certain preferences, for food for instance, may facilitate the establishment of 'ethnic identity' by defining persons, classes or groups of people. Although cognisant of possible race induced differences and preferences, the study is spurred by the conviction that students can sometimes appear monolithic to hypothesise that:

$\mathbf{H}_{2}$ : There is no relationship between race and students' service quality perception of campus-based food outlets.

\section{Price and service quality perception}

Customers typically rely on price to form an expectation about a specific food outlet, albeit the level of service quality that it can deliver (Ali, Amin \& Ryu 2016:49; Kwun, Ellyn \& Choi 2013:279). Price is a subjective concept as consumers may perceive a positive or negative relationship between price and value. The price and value relationship may in turn impinge upon the consumer's intention to purchase the product or service, as consumers tend to make a comparison between the overall benefits gained and perceived costs paid or sacrifices made to obtain that product or service (Bolton, Warlop \& Alba 2003:488; Choi et al. 2013:350; Ryu et al. 2011:204).

Consumers are willing to pay a reasonable price when purchasing food (Kwun et al. 2013:280) while also paying attention to portion size, affordability and value (Ali \& Ryu 2015:237). In a university context, many food outlets are available to students and this makes it difficult for food service providers to attract and retain students (Choi et al. 2013:357). Because of budgetary constraints that are typical of a student population, it can be argued that they would desire good service quality at reasonably low costs. Food outlets that address expected needs may enhance the overall experience of customers and consequently achieve a higher perceived value of service (Ali \& Ryu 2015:244). The role of price in the determination of service quality cannot be overemphasised as Ali et al. (2016:49) opine that price is encoded in a manner that is meaningful to the consumer and therefore influences their service quality perceptions. Although the study acknowledges this seemingly compelling argument, it hypothesises in the null form that:

$\mathbf{H}_{3}$ : There is no relationship between price and students' service quality perception of campus-based food outlets.

\section{Methodology}

Saunders, Lewis and Thornhill's (2009:138) research onion was adopted as a framework for creating the methodological pathway that was followed in the execution of the study. From a philosophical standpoint, the study was undertaken with a positivist orientation as the researchers had a clear preference for empiricism and objectivity. A deductive approach was utilised for the formulation of the study's hypotheses, while a survey strategy was the preferred choice for accessing members of the target population which were students of a university in South Africa.

The target population consisted of current students who had bought and consumed food from any of the numerous campus-based food outlets at the university. The convenience 
sampling technique that belongs in the family of nonprobability sampling methods was deployed primarily because of the non-existence of a sampling frame of patrons of campus-based food outlets and also for reasons of accessibility. According to Daniel (2012), the non-probability sampling technique enables the selection of sample members to reflect characteristics of the targeted population that are of interest to the study. Consequently, in the sample of 200 students utilised in the study, there was a satisfactory reflection of the relevant demographic diversity, particularly in terms of race and gender, which was critical for the intended investigation.

A self-administered questionnaire was utilised for the purpose of data collection. The specific method for the distribution and collection of the pre-tested questionnaires was a central-location intercept survey. The instrument contained scales comprising 7-point Likert items, for measuring service quality perceptions based on the SERVQUAL/DINESERV models as these had been used in previous studies by other researchers (see Du Plooy et al. 2013; Kukanja 2017; Shahzadi et al. 2018; Tayag \& Chere 2017). The response options on the study's service quality

TABLE 1: Item-total statistics for the SERVQUAL/DINESERV scale.

\begin{tabular}{|c|c|c|}
\hline Variables & $\begin{array}{l}\text { Corrected item-total } \\
\text { correlation }\end{array}$ & $\begin{array}{l}\text { Cronbach's alpha if } \\
\text { item deleted }\end{array}$ \\
\hline $\begin{array}{l}\text { Provision is made for customers' } \\
\text { suggestions and comments }\end{array}$ & 0.358 & 0.926 \\
\hline The menu has a good variety & 0.530 & 0.923 \\
\hline Presentation of the food is attractive & 0.557 & 0.923 \\
\hline Employees can be trusted & 0.435 & 0.925 \\
\hline $\begin{array}{l}\text { All food items portrayed on the menu } \\
\text { are available }\end{array}$ & 0.385 & 0.925 \\
\hline The order is fulfilled on time as promised & 0.493 & 0.924 \\
\hline $\begin{array}{l}\text { The waiting time to be served is } \\
\text { acceptable }\end{array}$ & 0.405 & 0.925 \\
\hline $\begin{array}{l}\text { The employees make customers feel } \\
\text { special }\end{array}$ & 0.563 & 0.923 \\
\hline The food outlet provides value for money & 0.496 & 0.924 \\
\hline Employees give speedy overall service & 0.542 & 0.923 \\
\hline Healthy food options are available & 0.366 & 0.926 \\
\hline $\begin{array}{l}\text { Employees have the knowledge to } \\
\text { answer questions }\end{array}$ & 0.566 & 0.923 \\
\hline The menu is attractive & 0.522 & 0.924 \\
\hline $\begin{array}{l}\text { Employees are never too busy to } \\
\text { respond to a request }\end{array}$ & 0.564 & 0.923 \\
\hline $\begin{array}{l}\text { The physical facilities are visually } \\
\text { appealing }\end{array}$ & 0.499 & 0.924 \\
\hline $\begin{array}{l}\text { Employees provide personal attention to } \\
\text { customers }\end{array}$ & 0.611 & 0.922 \\
\hline $\begin{array}{l}\text { The serving size of the food is } \\
\text { satisfactory }\end{array}$ & 0.473 & 0.924 \\
\hline Employees understand customer needs & 0.658 & 0.922 \\
\hline The food is of appropriate temperature & 0.582 & 0.923 \\
\hline $\begin{array}{l}\text { Employees show a sincere interest in } \\
\text { solving customer problems }\end{array}$ & 0.645 & 0.922 \\
\hline The order is correct and complete & 0.468 & 0.924 \\
\hline Customers feel a sense of personal safety & 0.517 & 0.924 \\
\hline Staff are neatly dressed & 0.535 & 0.923 \\
\hline Employees are polite & 0.595 & 0.923 \\
\hline The food is tasty and flavourful & 0.636 & 0.922 \\
\hline Employees are always willing to help & 0.689 & 0.922 \\
\hline The employees are patient & 0.692 & 0.921 \\
\hline The food is fresh & 0.665 & 0.921 \\
\hline The menu is easy to read & 0.416 & 0.925 \\
\hline
\end{tabular}

perception scale ranged from 1 ('strongly disagree') to 7 ('strongly agree'). The item-total statistics for the 29-item SERVQUAL/DINESERV instrument are shown in Table 1. The 'Cronbach's alpha if item deleted' presents values that are smaller than or equal to the scale's aggregate Cronbach's alpha value of 0.926 . Therefore, the deletion of any individual scale items will not improve the reliability of the scale and so all the items were retained.

Price perceptions were also measured with 7-point Likert items and the specific scale utilised had been used in a study conducted by Ali et al. (2016). The Cronbach's alpha value determined for the price perception scale was 0.912 , which suggests acceptable internal consistency. As shown in Table 2, the values for the 'Cronbach's alpha if item deleted' are 0.892 , 0.829 and 0.900 . All of these values are smaller than the scale's Cronbach's alpha value of 0.912 and so the deletion of any individual scale items will not improve the reliability of the scale. Consequently, all the scale items were retained.

Each respondent provided answers to all scale items measuring service quality perception and price perception. These responses were averaged to obtain an overall service quality or price perception score. The higher the respondent's composite score, the more positive their perception was regarding service quality or pricing of campus-based food outlets.

\section{Ethical considerations}

The data collection process only commenced after the ethical clearance application was approved and a permit number 13276256/2016 authorising the study was issued. All respondents were required to complete a consent form prior to completing the questionnaire. The consent form contains a brief explanation of the purpose of the study but the researchers also briefly discussed the purpose with respondents and explained the contents of the questionnaire. Furthermore, no incentives were given to customers for their participation in the study.

\section{Presentation of findings}

It was necessary for the sample population to contain reasonably equal numbers of persons with the demographic characteristics of gender and race that were of particular interest to the study. Table 3 presents the distribution of respondents in terms of race and gender. Black people and white people made up $36 \%$ and $38 \%$ of the sample, respectively. It is acknowledged that quota sampling, in

TABLE 2: Item-total statistics for the price perception scale.

\begin{tabular}{lcc}
\hline Variables & $\begin{array}{c}\text { Corrected item-total } \\
\text { correlation }\end{array}$ & $\begin{array}{c}\text { Cronbach's alpha if } \\
\text { item deleted }\end{array}$ \\
\hline $\begin{array}{l}\text { The prices charged at campus food } \\
\text { outlets are reasonable }\end{array}$ & 0.804 & 0.892 \\
$\begin{array}{l}\text { The prices charged at campus food } \\
\text { outlets are fair for a student budget }\end{array}$ & 0.878 & 0.829 \\
$\begin{array}{l}\text { The prices charged at campus food } \\
\text { outlets are appropriate for a } \\
\text { university setting }\end{array}$ & 0.793 & 0.900 \\
\hline
\end{tabular}


TABLE 3: A socio-demographic profile of respondents based on race and gender.

\begin{tabular}{lcc}
\hline Demographics & Number in sample $(\boldsymbol{N})$ & Valid percentage (\%) \\
\hline Race & 72 & \\
Black & 76 & 36.0 \\
White & 52 & 38.0 \\
Other & $\mathbf{2 0 0}$ & 26.0 \\
\hline Total & & $\mathbf{1 0 0 . 0}$ \\
\hline Gender & 99 & \\
Male & 101 & 49.5 \\
Female & $\mathbf{2 0 0}$ & 50.5 \\
\hline Total & & $\mathbf{1 0 0 . 0}$
\end{tabular}

TABLE 4: Mean and standard deviation for items in the SERVQUAL/DINESERV scale $(N=200)$

\begin{tabular}{|c|c|c|}
\hline Scale items & Mean & Standard deviation \\
\hline Overall service quality perception & 4.76 & 0.85 \\
\hline The menu is easy to read & 5.76 & 1.29 \\
\hline The order is correct and complete & 5.75 & 1.18 \\
\hline $\begin{array}{l}\text { All food items portrayed on the menu } \\
\text { are available }\end{array}$ & 5.41 & 1.47 \\
\hline Staff are neatly dressed & 5.41 & 1.28 \\
\hline The food is of appropriate temperature & 5.37 & 1.51 \\
\hline The food is tasty and flavourful & 5.36 & 1.45 \\
\hline Employees can be trusted & 5.33 & 1.27 \\
\hline $\begin{array}{l}\text { The order is fulfilled on time as } \\
\text { promised }\end{array}$ & 5.19 & 1.52 \\
\hline $\begin{array}{l}\text { Customers feel a sense of personal } \\
\text { safety }\end{array}$ & 5.16 & 1.28 \\
\hline The food is fresh & 5.08 & 1.58 \\
\hline $\begin{array}{l}\text { The waiting time to be served is } \\
\text { acceptable }\end{array}$ & 5.06 & 1.64 \\
\hline Employees are polite & 4.99 & 1.50 \\
\hline Presentation of the food is attractive & 4.79 & 1.57 \\
\hline $\begin{array}{l}\text { Employees have the knowledge to } \\
\text { answer questions }\end{array}$ & 4.76 & 1.25 \\
\hline Employees are always willing to help & 4.73 & 1.34 \\
\hline $\begin{array}{l}\text { The serving size of the food is } \\
\text { satisfactory }\end{array}$ & 4.70 & 1.63 \\
\hline The menu has a good variety & 4.67 & 1.62 \\
\hline The employees are patient & 4.64 & 1.49 \\
\hline The menu is attractive & 4.61 & 1.38 \\
\hline Employees give speedy overall service & 4.60 & 1.60 \\
\hline Employees understand customer needs & 4.45 & 1.33 \\
\hline $\begin{array}{l}\text { Employees are never too busy to } \\
\text { respond to a request }\end{array}$ & 4.40 & 1.52 \\
\hline $\begin{array}{l}\text { The physical facilities are visually } \\
\text { appealing }\end{array}$ & 4.32 & 1.52 \\
\hline $\begin{array}{l}\text { The food outlet provides value for } \\
\text { money }\end{array}$ & 4.26 & 1.78 \\
\hline Healthy food options are available & 4.10 & 1.86 \\
\hline $\begin{array}{l}\text { Employees provide personal attention to } \\
\text { customers }\end{array}$ & 4.09 & 1.46 \\
\hline $\begin{array}{l}\text { Employees show a sincere interest in } \\
\text { solving customer problems }\end{array}$ & 4.06 & 1.47 \\
\hline $\begin{array}{l}\text { The employees make customers feel } \\
\text { special }\end{array}$ & 3.74 & 1.53 \\
\hline $\begin{array}{l}\text { Provision is made for customers' } \\
\text { suggestions and comments }\end{array}$ & 3.33 & 1.61 \\
\hline
\end{tabular}

terms of race, was not a consideration for the study. This is partially because the race proportions within a university environment are not necessarily true reflections of the race composition in larger society. This throws up the dilemma of which specific race composition proportions to rely upon in determining representative quotas. Although the original intention was to also include other specific races, the numbers of such students in the sample did not permit this, and so students of different descents, save for black people and
TABLE 5: Mean and standard deviation for items in the Price Perception Scale $(N=200)$.

\begin{tabular}{lcc}
\hline Scale items & Mean & Standard deviation \\
\hline $\begin{array}{l}\text { Overall price perceptions. } \\
\begin{array}{l}\text { The prices charged at campus food outlets } \\
\text { are reasonable. }\end{array}\end{array}$ & 3.46 & 1.54 \\
$\begin{array}{l}\text { The prices charged at campus food outlets } \\
\text { are fair for a student budget. }\end{array}$ & 3.22 & 1.72 \\
$\begin{array}{l}\text { The prices charged at campus food outlets } \\
\text { are appropriate for a university setting. }\end{array}$ & 3.62 & 1.64 \\
\hline
\end{tabular}

TABLE 6: Overall service quality perception mean scores and standard deviations $(N=200)$.

\begin{tabular}{lccc}
\hline Cohort & Population $(\boldsymbol{N})$ & Mean $(\boldsymbol{M})$ & Standard deviation (SD) \\
\hline All respondents & 200 & 4.76 & 0.850 \\
Black & 72 & 4.54 & 0.834 \\
White & 76 & 4.87 & 0.749 \\
Other & 52 & 4.91 & 0.955 \\
Male & 99 & 4.82 & 0.813 \\
Female & 101 & 4.71 & 0.884 \\
\hline
\end{tabular}

$N$, number.

white people, were placed together in an 'other' race category, and this group accounted for $26 \%$ of the study sample. The $26 \%$ comprised of Chinese, Indian, mixed race, Hispanic, Latino and Arab students among others. As it pertains to gender, there were 99 males and 101 females in the study's respondent population.

Based on responses obtained from a 7-point Likert type scale, the average overall students' service quality perception of campus-based food outlets, as depicted in Table 4, is slightly positive $(M=4.76)$ with a standard deviation (SD) of 0.85 . The highest item mean score was 5.76, and this was associated with the 'menu is easy to read' statement, while the lowest mean score of 3.33 is linked to the 'provision is made for customers' suggestions and comments' statement. This indicates that most of the campus-based food outlets could be deemed not to be sufficiently sensitive to students' suggestions. It is important to note that the low value of the $\mathrm{SD}$ for items on the scale suggests some degree of agreement among the cohort of students that responded to the study, as it pertains to their perception of the service quality of campusbased food outlets.

Table 5 displays the mean and SD scores for items in the price perception scale. The overall mean score for the items on the 7-point Likert scale and the associated SD are 3.54 and 1.72, respectively. This indicates that the students in the respondent population tended to disagree with the statements typically suggesting that the prices charged at the campus-based food outlets are reasonable and befitting of a campus environment. Indeed, the mean score of 3.22 linked to the statement 'the prices charged at campus food outlets are fair for a student budget' suggests that students in the study's respondent population consider prices charged at the campus-based food outlets to be excessive. In the light of this, patronage of campus-based food outlets may be at risk.

As shown in Table 6, it is interesting to note that students in the 'other' race category held the most positive perception of service quality $(M=4.91)$ when compared to the 'black' or 
'white' students' categories. Gender-wise, the study found that male students had a higher service quality perception $(M=4.82)$ of campus-based food outlets in comparison with female counterparts $(M=4.71)$.

\section{Test of hypothesis 1}

Hypothesis 1 suggested the absence of a difference between male and female students' service quality perceptions of campus-based food outlets. The stated hypothesis was nondirectional and was tested at a $5 \%$ level of significance. The overall service quality perception was measured at an interval level, and a normality test of the distribution of responses was conducted using the Kolmogorov-Smirnov test. The results as shown in Table 7 signal that a normal distribution of responses exists for service quality perception and gender as the $p$-values for males $(p=0.09)$ and females $(p=0.11)$ are greater than the chosen 0.05 level of significance.

As shown in Table 8, the results for Levene's test for equality of variances $(p=0.386)$ and the $t$-test for equality of means $(p=0.355)$ are both greater than 0.05 , and so the null hypothesis cannot be rejected. These results therefore suggest that there is no statistically significant difference in the service quality perceptions of campus-based food outlets between males and females and so hypothesis 1 is accepted.

\section{Test of hypothesis 2}

This hypothesis suggested that the service quality perception of students would not differ along racial lines. As stated, the hypothesis was non-directional and was tested at a 5\% level of significance. This hypothesis involved three distinct groups ('black', 'white' and 'other') measured against the same variable (service quality perception) at an interval level and so the one-way analysis of variance (ANOVA) test was utilised. However, in order to conduct this test, it was imperative to ascertain that the responses satisfied the assumptions of normality and equal variances. As the $p$-values of all racial groups (as shown in Table 9) are greater than 0.05, the assumption of normality does hold for all racial subgroups.

In order to ascertain that the assumption of equal variances is satisfied, a Levene's test was conducted. A p-value of 0.303

TABLE 7: Test of normality of distribution of responses (service quality perception and gender).

\begin{tabular}{lccc}
\hline $\begin{array}{l}\text { Service quality } \\
\text { perception by } \\
\text { gender }\end{array}$ & Statistic & $\boldsymbol{d}$ & $\boldsymbol{p}$ \\
\cline { 2 - 4 } & 0.083 & 99 & 0.090 \\
Male & 0.080 & 101 & 0.110 \\
\hline Female & &
\end{tabular}

$\dagger$, Lilliefors significance correction; $d f$, degrees of freedom. $(p>0.05)$ was obtained and so the assumption of equal variances does hold making it statistically justifiable to conduct a one-way ANOVA test.

According to the results of the one-way ANOVA test (Table 10), the $p$-value of 0.020 is less than 0.05 and this therefore indicates a statistically significant difference in the service quality perceptions of racial groups. Therefore, the null hypothesis is rejected. However, these results do not reveal which group differs from the other. As a significant difference among groups exists, a post hoc comparison test was conducted to determine which specific racial group differs from the others. In instances where the assumption of homogeneity of variances does hold and the group sizes are slightly unequal, Field (2013:459) recommends the use of Gabriel's procedure and the results are presented in Table 11.

According to the results in Table 11, the overall service quality perceptions of the 'black' and the 'white' racial groups bear a statistically significant difference because the results reflect a $p$-value of 0.048 which is less than 0.05 . The results also show that the overall service quality perceptions of the 'other' racial category did not differ significantly from those of the 'black' and 'white' racial groups given the respective $p$-values of 0.05 and 0.995 .

\section{Test of hypothesis 3}

The hypothesis, expressed in its null form, suggested the absence of a relationship between price and students' service quality perception. The non-directional hypothesis was tested at a $5 \%$ level of significance. As both variables were measured at an interval level, Pearson's product moment correlation test (a parametric test) could be utilised granted that the assumptions of normality and linearity were satisfied (Diamantopoulos \& Schlegelmilch 2000:203). If these assumptions are not satisfied, then the Spearman's rank-order correlation test (a non-parametric test) would be an appropriate option to be utilised (Field 2009:179; Pallant 2011:128).

Based on the results of the Kolmogorov-Smirnov test for normality conducted, a normal distribution does not exist as the $p$-values obtained for service quality perception $(p=0.017)$

TABLE 9: Test of normality of distribution of responses (service quality perception and race).

\begin{tabular}{|c|c|c|c|}
\hline \multirow{2}{*}{$\begin{array}{l}\text { Service quality } \\
\text { perception by race }\end{array}$} & \multicolumn{3}{|c|}{ Kolmogorov-Smirnov $\dagger$} \\
\hline & Statistic & $d f$ & $p$ \\
\hline Black & 0.070 & 72 & 0.200 \\
\hline White & 0.080 & 76 & 0.200 \\
\hline Other & 0.113 & 52 & 0.095 \\
\hline
\end{tabular}

$\dagger$, Lilliefors significance correction; $d f$, degrees of freedom.

TABLE 8: Results of the independent sample $t$-test.

\begin{tabular}{|c|c|c|c|c|c|c|c|}
\hline \multirow{2}{*}{$\begin{array}{l}\text { Service quality } \\
\text { perception } \\
\text { variances }\end{array}$} & \multicolumn{2}{|c|}{ Levene's test for equality of variances } & \multicolumn{5}{|c|}{$t$-test for equality of means } \\
\hline & $F$ & $p$ & $t$ & $d f$ & $p$ (2-tailed) & Mean difference & Standard error difference \\
\hline $\begin{array}{l}\text { Equal variances } \\
\text { assumed }\end{array}$ & 0.755 & 0.386 & 0.928 & 198 & 0.355 & 0.111 & 0.120 \\
\hline $\begin{array}{l}\text { Equal variances not } \\
\text { assumed }\end{array}$ & - & - & 0.929 & 197.211 & 0.354 & 0.111 & 0.120 \\
\hline
\end{tabular}

$d f$, degrees of freedom; $t$, -statistics; $F, F$-statistic. 
TABLE 10: Results for the one-way analysis of variance test.

\begin{tabular}{lccccc}
\hline Variables & Sum of squares & $d f$ & Mean square & $\boldsymbol{F}$ & $\boldsymbol{p}$ \\
\hline Between groups & 5.557 & 2 & 2.779 & 3.967 & 0.020 \\
Within groups & 138.004 & 197 & 0.701 & - & - \\
\hline Total & $\mathbf{1 4 3 . 5 6 2}$ & $\mathbf{1 9 9}$ & - & - & - \\
\hline
\end{tabular}

$d f$, degrees of freedom; $t$, $t$-statistics; $F, F$-statistic.

TABLE 11: Results of the post hoc comparison test based on Gabriel's procedure

\begin{tabular}{lcccc}
\hline Race & Variables & Mean difference & Standard error & $\boldsymbol{p}$ \\
\hline Black & White & $-0.333^{*}$ & 0.138 & 0.048 \\
& Other & -0.365 & 0.152 & 0.050 \\
\multirow{2}{*}{ White } & Black & $0.333^{*}$ & 0.138 & 0.048 \\
& Other & -0.032 & 0.151 & 0.995 \\
Other & Black & 0.365 & 0.152 & 0.050 \\
& White & 0.032 & 0.151 & 0.995 \\
\hline
\end{tabular}

*, The mean difference is significant at the 0.05 level.

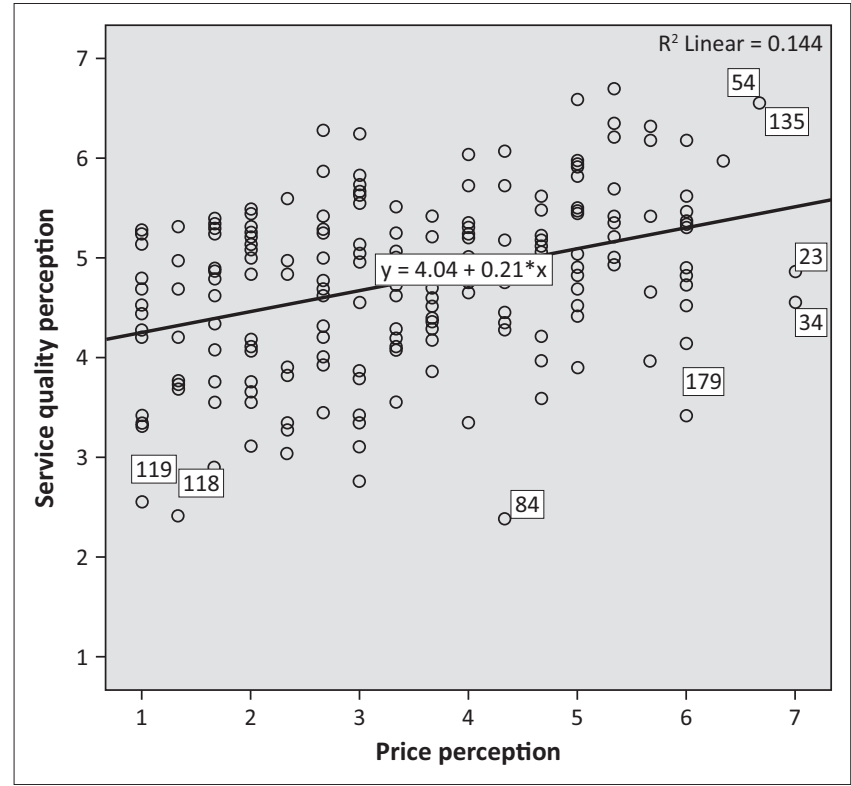

FIGURE 1: Scatterplot of service quality perception and price perception.

TABLE 12: Results of Spearman's rho rank-order correlation test.

\begin{tabular}{lc}
\hline Overall price perception & Service quality perception \\
\hline Correlation coefficient & 0.353 \\
$p$ (1-tailed) & 0.000 \\
$N$ & 200 \\
\hline
\end{tabular}

and price perception $(p=0.000)$ were less than 0.05 . The second prerequisite assumption of linearity was investigated with the scatterplot depicting the relationship between service quality perception and price perception (Figure 1). A relatively weak positive correlation between the two variables exists as the regression line has a positive gradient of 0.21 . Therefore, the assumption of linearity is met. Nonetheless, as the assumption of normality was not met, the Spearman's rank-order correlation test was utilised.

According to the results of Spearman's rank-order correlation test (Table 12), the $p$-value of 0.000 is less than the prescribed 0.05 level of significance. Therefore, the null hypothesis that suggests the absence of a relationship between price and service quality perception was rejected even though the strength of association between the two variables of interest is fairly weak but positive given the correlation coefficient of 0.353 .
The positive nature of the relationship relays that as the prices increase in campus-based food outlets, so does the students' perception of service quality. In other words, the result communicates that students' perception of quality increase with price. Students in the respondent population of the study can therefore be said to have a higher quality perception of campus-based food outlets that charge higher prices for their products.

\section{Limitations and recommendations for future research}

As this study utilised a non-probability sampling approach, the results obtained may not be generalised across a larger population (Saunders et al. 2009:213). This limitation is also relevant in the light of the influence that geographical and cultural contexts could have on quality perceptions. It is also possible that the study was susceptible to social desirability bias. Social desirability bias relates to a situation where students tend to alter their responses according to what is believed to be correct by either the interviewer, peers or society. This error likely occurred as the researchers approached students outside food outlets and lecture halls where they tend to gather in groups. It is recommended that future studies that seek to explore relationships between variables similar to those used in this study should adopt a probability technique so as to make the findings generalisable to a broader population. Further, the use of a multivariate approach for the exploration of the concurrent interplay between study variables would add value to findings as these variables are for practical intents, usually coincidental.

\section{Discussion and conclusion}

The purpose of this study was to investigate the relationship between the independent variables of gender, race and price and the dependent variable of students' service quality perception of campus-based food outlets. The study found that the overall students' service quality perception $(M=4.76$, $\mathrm{SD}=0.85$ ) was fairly positive. The study also revealed that no significant difference exists between male and female service quality perception of campus-based food outlets. A possible reason for the finding may be that the food outlets are providing a service that caters for students in general. Thus, the respondents may have viewed service quality from a broad student perspective and not based on gender. The finding of this study aligns with those of Du Plooy et al. (2013:110), Josiam et al. (2014:66) and Lin et al. (2014:315) but contradicts the findings of Lu and Wang (2015:747), Mokhlis (2012:108) and Sumaedi et al. (2012:177).

Furthermore, the study found that a significant difference exists in service quality perceptions across racial lines. This may be because of the differences in the cultures of the racial groups. Also given that South Africa is a multiracial country that inhabits rich cultures, it may be possible that students' cultures subconsciously influence their perceptions. Interestingly, the 'other' racial group held the highest SD 
(0.955), suggesting that their responses varied the most. A possible explanation for this may be that this group was more racially heterogeneous than the others as it comprised students of Chinese, Indian, Filipino and mixed race descent among others. The study's findings that service quality perceptions differ according to racial groups agree with the position of Maumbe (2012:160) but is opposed to that of Terblanche and Boshoff (2010:6).

The study exposed the existence of a weak positive correlation that exists between price and service quality perception. A possible reason for the weak correlation is that students may not be entirely satisfied and may believe that there is room for improvement with regard to the services that are rendered and the prices that are charged. This finding aligns with those of Ali et al. (2016:49), Ali and Ryu (2015:244) and Kwun et al. (2013:279).

The study's results bode managerial implications and provide insightful knowledge to campus-based food outlets about how students perceive their service offerings. For instance, the findings suggest that campus-based food outlets do not have to customise their service offerings according to gender but should rather worry about racially induced preferences. The implication of this is that campus-based food outlets may wish to consider traditional service offerings that appeal to specific racial groups. In addition, it might be appealing to consider the use of workers of different races in campus-based food outlets. This is likely to enable ease of interaction between patrons and workers and ultimately allow the food outlets to benefit from the natural affinity that often exists between persons of same racial descents. Campus-based food outlets may also wish to consider the creation of some special themes for each race group on an episodic basis as this might appeal to students of specific race make-ups. Furthermore, the study found that students believe that the prices charged by campus-based food outlets is not exactly in line with the budget of a student. As students hold such negative price perceptions, campus-based food outlets could either maintain their current level of service offerings and reduce prices, or improve their current level of service offerings and make no adjustments to prices. This is reasonable on the premise of the determined positive relationship that exists between price and students' service quality perception.

\section{Acknowledgements Competing interests}

The authors declare that they have no financial or personal relationships that may have inappropriately influenced them in writing this article.

\section{Authors' contributions}

C.E.E-E. was the research lead and was responsible for writing up the paper. M.A.S. and R.S. were responsible for the literature review, data collection and statistical analysis.

\section{References}

Ali, F., Amin, M. \& Ryu, K., 2016, 'The role of physical environment, price perceptions, and consumption emotions in developing customer satisfaction in Chinese resort hotels', Journal of Quality Assurance in Hospitality \& Tourism 17(1), 45-70. https://doi.org/10.1080/1528008X.2015.1016595

Ali, F. \& Ryu, K., 2015, 'Bringing them back to spend more: Student foodservice experiences to satisfy their taste buds', Young Consumers 16(2), 235-248. https:// doi.org/10.1108/YC-05-2014-00441

Bolton, L., Warlop, L. \& Alba, J., 2003, 'Consumer perceptions of price (un)fairness', The Journal of Research 29(4), 474-491. https://doi.org/10.1086/346244

Cao, Y. \& Kim, K., 2015, 'How do customers perceive service quality in differently structured fast food restaurants?', Journal of Hospitality Marketing \& Management 24, 99-117. https://doi.org/10.1080/19368623.2014.903817

Choi, E., Wilson, W. \& Fowler, D., 2013, 'Exploring customer experiential components and the conceptual framework of customer experience, customer satisfaction, and actual behaviour', Journal of Foodservice Business Research 16(4), 347-358. $\mathrm{https}$ ://doi.org/10.1080/15378020.2013.824263

Chou, C., Wu, P. \& Huang, C., 2014, 'Service climate, service convenience, service quality and behavioural intentions in chain store restaurants', International Journal of Organizational Innovation 7(1), 161-170.

Cronin, J. \& Taylor, S., 1992, 'Measuring service quality: A re-examination and extension', Journal of Marketing 56(3), 55-68. https://doi.org/10.2307/1252296

Dabestani, R., Shahin, A., Saljoughian, M. \& Shirouyehzad, H., 2016, 'Importanceperformance analysis of service quality dimensions for the customer groups segmented by DEA: The case of four star hotels', International Journal of Quality \& Reliability Management 33(2), 160-177. https://doi.org/10.1108/IJQRM-02-2014-0022

Daniel, J., 2012, Sampling essentials: Practical guidelines for making sample choices, Sage, Thousand Oaks, CA.

Dedeoglu, B. \& Demirer, H., 2015, 'Differences in service quality perceptions of stakeholders in the hotel industry', International Journal of Contemporary Hospitality Management 27(1), 130-146. https://doi.org/10.1108/IJCHM-082013-0350

Denton, M. \& Vloeberghs, D., 2003, 'Leadership challenges for organisations in the new South Africa', Leadership \& Organization Development Journal 24(2), 84-95. https://doi.org/10.1108/01437730310463279

Diamantopoulos, A. \& Schlegelmilch, B., 2000, Taking the fear out of data analysis: A step-by-step approach, London Business Press, London.

Domenge, R. \& Arciniega, L., 2015, 'Development of a short questionnaire for measuring service quality perceptions', Decision 42(1), 11-17. https://doi.org/ 10.1007/s40622-015-0072-6

Draai, E. \& Raga, K., 2012, 'Quality public services: A South African perspective', Africa Insight 42(2), 185-199.

Duggal, E. \& Verma, H., 2013, 'Service quality: Construct comprehension and evolution over time', Journal of Services Research 13(1), 135-160.

Du Plooy, A., De Jager, J. \& Van Zyl, D., 2013, 'Drivers of perceived service quality in selected informal grocery retail stores in Gauteng, South Africa', South African Business Review 16(1), 94-121.

El-Said, O. \& Fathy, E., 2012, 'Assessing university students' satisfaction with on campus cafeteria services', Tourism Management Perspectives 16, 318-324. https://doi.org/10.1016/j.tmp.2015.09.006

Field, A., 2009, Discovering statistics using SPSS, 3rd edn., Sage, Thousand Oaks, CA.

Field, A., 2013, Discovering statistics using IBM SPSS Statistics, Sage, Thousand Oaks, CA.

Fonseca, M., 2008, 'Understanding consumer culture: The role of "food" as an important cultural category', Latin American Advances in Consumer Research 2, 28-33.

Gagic, S., 2013, 'The vital components of restaurant quality that affect guest satisfaction', Turizam 17(4), 166-176. https://doi.org/10.5937/Turizam1304166G

Jiang, J., Klein, G., Parolia, N. \& Yuzhu, L., 2012, 'An analysis of three SERVQUAL variations in measuring information system service quality', The Electronic Journa Information Systems Evaluation 15(2), 149-227.

Jiang, Y. \& Wang, C., 2006, 'The impact of affect on service quality and satisfaction: The moderation of service contexts', Journal of Services Marketing 20(4), 211-218. https://doi.org/10.1108/08876040610674562

Josiam, B., Foster, C., Malave, R. \& Baldwin, W., 2014, 'Assessing quality of food, service and customer experience at a restaurant: The case of a student run restaurant in the USA', Journal of Services Research 14(1), 49-73.

Judson, K. \& Taylor, S., 2014, 'Moving from marketization to marketing of higher education: The co-creation of value in higher education', Higher Education Studies 4(1), 51-67. https://doi.org/10.5539/hes.v4n1p51

Kanta, K. \& Srivalli, P., 2014, 'A study on factors influencing service quality in restaurants', Annamalai International Journal of Business Studies \& Research 6(1), 1-9.

Karna, S. \& Julin, P., 2015, 'A framework for measuring student and staff satisfaction with university campus facilities', Quality Assurance in Education 23(1), 47-66. https://doi.org/10.1108/QAE-10-2013-0041

Kilinc, C., Semiz, M., Katircioglu, E. \& Unusan, C., 2013, 'Choosing a restaurant for lunch in campus area by the compromise decision via AHP', International Journal of Economic Perspectives 7(2), 5-10.

Kim, W., Ng, C. \& Kim, Y., 2009, 'Influence of institutional DINESERV on customer satisfaction, return intention, and word-of-mouth', International Journal of
Hospitality Management 28(1), 10-17. https://doi.org/10.1016/j.ijhm.2008. 03.005 
Kukanja, M., 2017, 'Quality measurement in restaurant industry from the marketing perspective: A comparison of guests' and managers' quality perceptions', Ekonomska misao i praksa 1, 41-61.

Kwun, D., Ellyn, E. \& Choi, Y., 2013, 'Campus foodservice attributes and their effects on customer-satisfaction, image, and word-of-mouth', Journal of Foodservice Business Research 16, 276-297. https://doi.org/10.1080/15378020.2013.810534

Lin, J., Hsiao, C., Glen, R., Pia, J. \& Zeng, S., 2014, 'Perceived service quality, perceived value, overall satisfaction and happiness of outlook for long-term care institution residents', An International Journal of Public Participation in Health Care and Health Policy 17(3), 311-320. https://doi.org/10.1111/j.1369-7625.2012.00769.x

Ltifi, M., 2013, 'Antecedents and effects of commitment on the impulse by internet', Journal of Internet Banking and Commerce 18(1), 2-22.

Lu, H. \& Wang, Y., 2015, 'Re-evaluating the roles of servicescape when customers are choosing a restaurant', Journal of Interdisciplinary Mathematics 18(6), 737-750. https://doi.org/10.1080/09720502.2015.1109301

Mokhlis, S., 2012, 'The influence of service quality on satisfaction: A gender comparison', Public Administration Research 1(1), 103-112. https://doi. org/10.5539/par.v1n1p103

Maumbe, B., 2012, 'The rise of South Africa's quick service restaurant industry', Journal of Agribusiness in Developing and Emerging Economies 2(2), 147-166. https://doi.org/10.1108/20440831211272607

Pallant, J., 2011, SPSS survival manual: A step by step guide to data analysis using SPSS version 18, 4th edn., Allen and Unwin, Australia, Crows Nest.

Parasuraman, A., Berry, L. \& Zeithaml, V., 1991, 'Refinement and reassessment of the SERVQUAL scale', Journal of Retailing 67(4), 420-450.

Parasuraman, A., Zeithaml, V. \& Berry, L., 1985, 'A conceptual model of service quality and its implications for future research', The Journal of Marketing 49(4), 41-50. https://doi.org/10.2307/1251430

Parasuraman, A., Zeithaml, V. \& Berry, L., 1988, 'SERVQUAL: A multiple-item scale fo measuring consumer perceptions of service quality', Journal of Retailing 64(1), 5-8.

Prentice, C., 2013, 'Service quality perceptions and customer loyalty in casinos', International Journal of Contemporary Hospitality Management 25(1), 49-64. https://doi.org/10.1108/09596111311290219
Rauch, D., Collins, M., Nale, R. \& Barr, P., 2015, 'Measuring service quality in mid-scale hotels', International Journal of Contemporary Hospitality Management 27(1), 87-106. https://doi.org/10.1108/IJCHM-06-2013-0254

Rust, R.T. \& Oliver, R.L., 1994, 'Service quality: Insights and managerial implications from the frontier', in R.T. Rust \& R.L. Oliver (eds.), Service quality: New directions in theory and practice, pp. 1-19, Sage, Thousand Oaks, CA.

Ryu, K., Lee, H. \& Kim, W., 2011, 'The influence of the quality of the physical environment, food, and service on restaurant image, customer perceived value, customer satisfaction, and behavioural intentions', International Journal of Contemporary Hospitality Management 24(2), 200-223. https://doi. org/10.1108/09596111211206141

Saunders, M., Lewis, P. \& Thornhill, A., 2009, Research methods for business students, 5th edn., Pearson, Harlow, UK.

Shahzadi, M., Malik, S., Ahmad, M. \& Shabbir, A., 2018, 'Perceptions of fine dining restaurants in Pakistan: What influences customer satisfaction and behaviora intentions?', International Journal of Quality \& Reliability Management 35(3), 635-655. https://doi.org/10.1108/IJQRM-07-2016-0113

Singh, P. \& Zheng, J., 2014, 'Toward a quality model for a UoT research centre in South Africa', South African Journal of Higher Education 28(1), 254-274.

Stevens, P., Knutson, B. \& Patton, M., 1995, 'DINESERV: A tool for measuring service quality in restaurants', Cornell Hotel and Restaurant Administration Quarterly 36(2), 56-60. https://doi.org/10.1177/001088049503600226

Sumaedi, S., Bakti, G. \& Metasari, N., 2012, 'An empirical study of state university students' perceived service quality', Quality Assurance in Education 20(2), 164183. https://doi.org/10.1108/09684881211219424

Tayag, M. \& Chere, C, 2017, 'Service quality of selected fast food restaurants in Angeles City', Ascendens Asia Journal of Multidisciplinary Research Conference Proceedings 1(2).

Terblanche, N. \& Boshoff, C., 2010, 'Quality, value, satisfaction and loyalty amongst race groups: A study of customers in the South African fast food industry', South African Journal of Business Management 41(1), 1-9.

Wu, P., Huang, C. \& Chou, C., 2014, 'Service expectation, perceived service quality, and customer satisfaction in food and beverage industry', International Journal of Organizational Innovation 17(1), 171-180. 